Pesq. Vet. Bras. 38(5):817-822, maio 2018

DOI: $10.1590 / 1678-5150-P V B-4673$

\title{
A retrospective study of causes for mortality of Thoroughbred horses in Caracas, Venezuela (2008-2012) ${ }^{1}$
}

\author{
Abelardo Morales Briceño ${ }^{2 *}$, José L. Méndez-Angulo ${ }^{3}$ \\ and Aniceto Méndez Sánchez ${ }^{2}$
}

\begin{abstract}
Briceño A.M., Méndez-Angulo J.L. \& Sánchez A.M. 2018. A retrospective study of causes of mortality of Thoroughbred horses in Caracas, Venezuela (20082012). Pesquisa Veterinária Brasileira 38(5):817-822. Departamento de Anatomía y Anatomía Patológica Comparadas, Edificio de Sanidad Animal, Colegio de Medicina Veterinaria, Universidad de Córdoba, Campus de Rabanales, Ctra. de Madrid Km 396, Córdoba, 14071, Spain. E-mail: aamorales13@gmail.com

The aim of this study was to describe the causes of death in Thoroughbred horses at the Racetrack "La Rinconada", in Caracas (Venezuela) during 2008-2012. This study was conducted in a cohort of all Thoroughbred horses that died or were subjected to euthanasia. Data was collected retrospectively. Only horses for which a full necropsy report was available were included in the study. The carcass and all internal organs of each horse were examined and representative samples of tissues with abnormalities were collected in $10 \%$ neutral buffered formalin and processed for histopathological examination. Samples were collected for bacteriological or virological examination when indicated in gross examination. A descriptive statistical analysis was performed. A total of 532 Thoroughbred horses were examined post-mortem. Of these horses, $44 \%$ were females and $56 \%$ males. In general musculoskeletal injuries and dilaceration occurred specifically at higher frequency. The total year and horses dead for descriptive statistical analysis was to mean 106.4 and median 125; Standard Deviation: 47.82573; variation (Standard Deviation): 2287.3, population (Standard Deviation): 42.77663 and variance (Standard Deviation): 18229.84. In conclusion we identify and describe the causes of death in Thoroughbred Race Horses in Caracas, Venezuela. In order of importance the causes of death were principally skeletal muscle injuries resulting in fractures euthanasia, abdominal crisis were mostly bowel twists and gastric rupture andrespiratory pathologies such as the pneumonia, pleuritis presented a significant number of cases of pulmonary hemorrhage induced by exercise. Finally the multisystem pathologies were presented in low cases.
\end{abstract}

INDEX TERMS: Mortality, Thoroughbred horses, Caracas, racehorse, musculoskeletal, equine, racing.

RESUMO.- [Estudo retrospectivo sobre causas de mortalidade em cavalos de Puro Sangue em Caracas, Venezuela (2008-2012).] O objetivo deste estudo foi descrever as causas de morte em cavalos de raça Puro Sangue

\footnotetext{
${ }^{1}$ Received on December 30, 2016.

Accepted for publication on May 3, 2017.

${ }^{2}$ Departamento de Anatomía y Anatomía Patológica Comparadas, Edificio de Sanidad Animal, Colegio de Medicina Veterinaria, Universidad de Córdoba, Campus de Rabanales, Ctra. de Madrid Km 396, Córdoba, 14071, Spain. *Corresponding author: aamorales13@gmail.com

${ }^{3}$ Departamento de Medicina y Cirugía Animal, Colegio de Medicina Veterinaria, Universidad de Córdoba, Campus de Rabanales, Ctra. de Madrid Km 396, Córdoba, 14071, Spain.
}

no rasto "La Rinconada", em Caracas, Venezuela, durante 20082012. Este estudo foi conduzido com cavalos Puro Sangue que morreram ou foram submetidos à eutanásia. Os dados foram escolhidos retroativamente. Somente cavalos com relatório de necropsia disponível foram incluídos neste estudo. Foram examinados o cadáver e todos os órgãos internos de cada cavalo e as amostras representativas de tecidos com anormalidades foram coletadas em $10 \%$ de formol neutro e processadas para exame histopatológico. As amostras foram apanhadas para o exame bacteriológico ou virológico somente quando indicadas em exame macroscópico. Uma análise estatística descritiva foi feita e um total de 532 cavalos Puro Sangue foi examinado através de necropsia. Destes cavalos, 
$44 \%$ eram fêmeas e 56\% machos. Em geral, rompimentos musculares esqueléticos ocorreram mais frequentemente. $\mathrm{O}$ ano total e cavalos de mortos para análise estatística descritiva foi em média 106.4, mediana 125; Padrão de Divergência: 47.82573; variação (padrão de Divergência): 2287.3, população (Padrão de Divergência): 42.77663 e discrepância (Padrão de Divergência): 18229.84. Para concluir, identificamos e descrevemos as causas de morte em Cavalos Raça de Puro Sangue em Caracas, Venezuela. As causas de norte, por ordem da importância, foram lesões do músculo esquelético que causaram fraturas e eutanásia, crises abdominais principalmente por distorção e a ruptura gástrica e patologias viventes como a pneumonia e a pleurisia apresentaram um número significante dos casos de hemorragia pulmonar induzida pelo exercício. Finalmente, as patologias multi-sistêmicas foram apresentadas em poucos casos.

TERMOS DE INDEXAÇÃO: Mortalidade, Puro Sangue, Caracas, músculo esquelético, equinos, corrida.

\section{INTRODUCTION}

Racing fatalities are an important welfare concern in Thoroughbred horses and they cause major economic losses to the equine racing industry (Boden et al. 2005). These fatalities include sudden deaths that occur while racing or training and horses that are euthanized due to catastrophic injuries (Boden et al. 2005, Lyle et al. 2011). Reported causes of death in Thoroughbred horses associated with racing or training include catastrophic musculoskeletal injury (CMI), acute abdominal crisis (colic), other major causes of death included respiratory, digestive and multi-organ system disorders (Johnson et al. 1994).

Several studies have showed that musculoskeletal injuries are the major cause of mortality in racing Thoroughbreds in the Australia, UK and USA. Necropsies were performed on 496 horses that had a fatal injury or illness at a California racetrack during the period February 20, 1990 to March 1, 1992 (Johnson et al. 1994). In a racing of Thoroughbreds in Britain, of the 2,358 clinical events reported (1.05\% of all starts), 1,937 involved the musculoskeletal system and 421 involved other body systems (Williams et al. 2001). Injuries result in $80 \%$ to $83 \%$ of deaths associated with racing and training (Johnson et al. 1994, Stover 2003).

The prevalence of catastrophic musculoskeletal injuries that resulted in death was $0.12 \%, 0.14 \%$, and $0.17 \%$ per race start for Thoroughbreds in Florida, Kentucky, and California, respectively (Stover 2003). In Minnesota, 3.2\% of horses that made at least one race start were euthanized, retired for breeding, or deemed unable to train for 6 months because of musculoskeletal injury (Stover 2003). In French the overall mortality rate was locomotor (21\%) (Leblond et al. 2000). During the study period (1989-2004), 180 deaths occurred during racing or training on racecourses throughout Victoria, Australia (Boden et al. 2006). In Victoria, Australia there were 514 fatalities over the 15 year period; 316 in flat races and 198 in jump races (Boden et al. 2006). Euthanasia following catastrophic musculoskeletal injury accounted for the other $74 \%$ (134/180). Musculoskeletal injuries besides other causes of death have been described in racehorses. Other major causes of death included respiratory (4\%), digestive (4\%), cardiovascular (3\%) and multi-organ system disorders (5\%)
(Johnson et al. 1994). In French the overall mortality rate was $2.47 \%$, and was due, in decreasing order, to foaling (24\%), colic $(21 \%)$, cardiovascular $(9 \%)$, neurological $(8 \%)$, respiratory $(5 \%)$ or infectious (4\%) disease (Leblond et al. 2000). Post mortem examinations were performed on $43 \%$ of horses (77/180), with $97 \%(61 / 63)$ of all metropolitan fatalities and $14 \%(16 / 117)$ of all country fatalities being submitted (Boden et al. 2005), sudden death accounted for $26 \%$ of all fatalities (46/180) of all fatalities on Victorian racetracks recorded during the study period (Boden et al. 2005).

Recently a study postmortem diagnoses in mature and aged equids, the most common cause of death as determined at autopsy of equids 15 years of age was disease of the digestive system, pituitary gland, locomotor system, or nervous system. Nervous system disease was more common in equids 15 to 19 years of age; urinary tract disease was more common in equids $\geq 20$ years of age (Miller et al. 2015). To the author's knowledge, there is a lack of scientific information on the causes of death of Thoroughbreds that race in highly populated racetracks of South America. The aim of this study was to describe the causes of mortality in Thoroughbred horses at the Racetrack "La Rinconada", in Caracas, Venezuela, during 2008-2012.

\section{MATERIALS AND METHODS}

Data collection. Data was collected retrospectively from the records of the Department of Pathology of the Racetrack "La Rinconada" in Caracas, Venezuela, which depends on the Animal Health Division attached to the Racetracks National Institute of Venezuela. The Horse Racing Regulation of Venezuela requires performing necropsy all horses that die during races in each race track is an official pathologist who is responsible for conducting the necropsy and sampling. The age, sex and activity of each horse at the time of death were reviewed and recorded. The age were classified in 2-year-old 53\% (280/532); 3 -year-old 31\% (166/532); 4-year-old 15\% (80/532); $\geq 5$-year-old $1 \%(06 / 532)$. Only horses for which a full necropsy report was available were included in the study.

Laboratory study. The carcass and all internal organs of each horse were examined and representative samples of tissues with abnormalities were collected in 10\% neutral buffered formalin and processed for histopathological examination. Samples were collected for bacteriological or virological examination when indicated in gross examination (Aluja \& Constantino 2002). Affected contralateral limbs were examined in horses subjected to euthanasia because of a limb injury. The skin and subcutaneous tissue was removed from the fore- and hindlimbs from the level of the shoulder or stifle joints to the hoof. The limbs were examined for signs of inflammation, hemorrhage and foreign material. The carpi, hocks and fetlock joints were disarticulated and joint surfaces examined thoroughly. Fractures and acute or chronic inflammatory changes were recorded for each limb. The primary cause for death or euthanasia was categorized by organ system, i.e. cardiovascular, musculoskeletal, digestive, integumentary, nervous, respiratory, urogenital and multi-system which included cases in which several organ systems were affected or no cause of death was determined. For musculoskeletal injuries, the affected limb and injury site was recorded. Additionally mortality was established annually and monthly for purposes of comparing time of year (summer-winter).

Statistical analysis. A descriptive statistical analysis was performed (calculating the mean, median, standard deviation and variance, with presentation of absolute frequencies and percentage 
of death number, number of lesions with a level of significance $\leq 5 \%$. A statistical analysis comparing student T-Test annual to compare the summer-winter the results were the following was collected.

\section{RESULTS}

This study was conducted in a cohort of all Thoroughbred horses that died or were subjected to euthanasia in the National Race Track "La Rinconada" Caracas, Venezuela between July 1, 2008 and July 1, 2012. The average annual population of horses training and competing at the racetrack "La Rinconada" between July 2008 and July 2012 was 1,900 horses population. In training and official race a total number of starts per week were 24 (12 races on Saturday and 12 on Sunday), including an average of 12 horses per race (include winter/summer). A total of 6,240 starts occurred during the study period (approximately, 1,242 starts per year) in date Commission Regulation National Horse Racing Venezuela 1995. A total of 532 Thoroughbred horses were examined post-mortem (Table 1). Of these horses, 44\% were females and 56\% males. The average annual mortality was 106 deaths per year horses and about 11 horses a month. Respect to the months of highest mortality apparently August has the highest number of cases. In general musculoskeletal injuries fractures occurred specifically at higher frequency. The collapse of the metacarpophalangeal joint without bone fracture, with over-stretching of ligaments, ligament and tendon rupture with subsequent subluxation occurred in a total of 26 horses (Table 2). The injuries were so severe that ultimately led to euthanasia. Regarding mortality associated with gastrointestinal pathologies was to observe two cases of esophagitis abscess with bacteremia and septicemia complication. The rupture of the stomach is present in 59 horses. The torsion of the small intestine was observed in 71 horses and torsion of large intestine was present in 30 cases. Volvulus occurred in 10 cases the small intestine and 9 cases in large intestine. Only were observed displacement of the base of the caecum in 7 cases. Only were observed two cases of incarceration thick segment intestine. The pathologies presented in the respiratory system were 75 cases. Pleuritis 6, pleuropneumonia 23 , pneumonia 8 , abscesses 7 , pulmonary hemorrhage 31. Infectious processes occurred in 16\%. The isolated bacteria were: Escherichia coli 64\%, Streptococcus equi subsp. zooepidemicus 17\%, Salmonella sp. $6 \%$, and in minor proportion Lawsonia intracelularis, Pasterella aeruginosa, Proteus mirabilis and Staphilococcus aureus. The total year and horses dead for descriptive statistical analysis was to mean (average): 106.4, median 125; Standard Deviation: 47.82573; variation (Standard Deviation): 2287.3, population (Standard Deviation): 42.77663 and variance (Standard Deviation): 18229.84. The descriptive statistical analysis of the skeletal muscle injury was to mean (average): 49, median 58. The digestives pathologies presented a mean (average) of 37.8 and median 41. Respiratory pathologies mean (average): 15 median 9 and multisystem pathologies mean (average) and median 4.64. The comparing time of year (summerwinter) period of winter months of May, June, July, August, September and October which present a total of $57 \%$ horses died during the study period. The summer period covers the months of November, December, January, February, March and April a total of $43 \%$ horses died during the study period. The winter means was to 60.8 and variance of 760.96 and
Table 1. Organ system affected for Thoroughbred horses by year of study in the Racetrack "La Rinconada” Caracas, Venezuela

\begin{tabular}{cccccc}
\hline Year & $\begin{array}{c}\text { Total } \\
\text { equine }\end{array}$ & Musculoskeletal & Digestive & Respiratory & $\begin{array}{c}\text { Multi- } \\
\text { System }\end{array}$ \\
\hline 2008 & 52 & 29 & 14 & 6 & 3 \\
2009 & 125 & 65 & 41 & 9 & 9 \\
2010 & 135 & 58 & 55 & 18 & 4 \\
2011 & 160 & 65 & 55 & 35 & 6 \\
2012 & 60 & 28 & 24 & 7 & 1 \\
TOTAL & 532 & 245 & 189 & 75 & 23
\end{tabular}

Table 2. Bones affected in limb fractures of Thoroughbreds in the Racetrack "La Rinconada" Caracas, Venezuela

\begin{tabular}{lccc}
\hline \multicolumn{1}{c}{ Forelimb } & Total & Left & Right \\
\hline First Phalanx & 4 & 3 & 1 \\
Proximal Sesamoid & 46 & 31 & 15 \\
Metacarpus & 28 & 16 & 12 \\
Carpus & 9 & 5 & 4 \\
Radius & 12 & 8 & 4 \\
Humerus & 14 & 8 & 6 \\
Scapula & 6 & 3 & 3 \\
Foreleg & & & \\
Tarsus & 2 & 0 & 2 \\
Metatarsus & 2 & 0 & 2 \\
Tibia & 13 & 7 & 6 \\
Femur & 2 & 1 & 1 \\
Axial Skeleton & & & \\
Skull & 20 & & \\
Vertebrae & 28 & & \\
Ribs & 20 & & \\
Pelvis & 13 & &
\end{tabular}

in the summer means was to 45.6 and a variance of 232.24 . A statistical analysis comparing student T-Test annual to compare the summer-winter the results were the following was collected. The value of $\mathrm{T}$ was: 1.0784 . The results are presented in the Tables.

\section{DISCUSSION}

These results suggest a high rate of mortality in horses racing in the Race track "La Rinconada" Caracas-Venezuela. The lesions were predominantly skeletal muscle and digestives. Although fatal musculoskeletal injuries have a low prevalence, milder forms of these injuries have a high prevalence (Stover 2003). The results of this study coincide with those presented by other authors (Stover 2003), where the main causes of mortality are catastrophic musculoskeletal injuries and gastrointestinal pathologies associated with colic. Most of the musculoskeletal injuries occurred while racing (42\%) and in training sessions (39\%); with fewer non-exercise $(12 \%)$ and accident $(7 \%)$ related injuries or illnesses (Stover 2003). Musculoskeletal injuries accounted for $83 \%$ of the Thoroughbred and $80 \%$ of the Quarter Horse submissions (Stover 2003). These results differ from those 
obtained in this study that reported $46 \%$ mortality associated with musculoskeletal injuries. Our results agree with those obtained by Johnson et al. (1994), since we have observed that the forelimbs are most affected, to a greater prevalence former member left than the right. The proximal sesamoid bones and suspensory apparatus with higher number of cases $46 / 239$, followed by the main metacarpal $28 / 239(12 \%)$. These results suggest the presence of previous injuries involving the proximal sesamoid bones, third metacarpal and suspensory apparatus. However bone lesions principal metacarpal level, followed by humerus radio, carpus and scapula were presented with marked frequency forelegs. The Thoroughbred horses incurred 306 fractures with 263 in the limbs and $90 \%$ of those in the forelimbs. The proximal sesamoid bone(s), third metacarpal bone and humerus were the most common bones fractured in Thoroughbred horses and Quarter Horses.

The presentation of laminitis was $8 \%(44 / 533)$ in relation to total necropsies in most cases was concomitant with rotation of the coffin bone, piercing the sole and osteomyelitis which was cultured and identified $E$. coli. These results are superior to those reported by Johnson et al. (1994), suggesting a laminitis mortality 2\%. Exogenous administration of glucocorticoids corresponds to a significant risk for developing adult laminitis in horses (Johnson et al. 2002). In these cases there was a pre-existing injury muscle-skeletal and prolonged treatment by NSAIDs and steroids which were confirmed by toxicological studies in blood and urine. Laminitis risk seems to be higher during treatment with certain glucocorticoids (dexamethasone and triamcinolone especially) compared to others (prednisone and prednisolone). (Johnson et al. 2002, Dutton 2007), these reports the results obtained. Other major causes of death included respiratory, digestive and multi-organ system disorders (Johnson et al. 1994). In Victoria, Australia the risk of fatality was 0.44 per 1000 flat starts and 8.3 per 1000 jump starts (18.9 x greater). The risk of fatality on city tracks was 1.1 per 1000 starts whereas on country tracks it was 0.57 per 1000 starts. Of the 316 fatalities in flat races, $73.4 \%$ were due to limb injury, $2.5 \%$ to cranial or vertebral injury and $19.0 \%$ were sudden deaths. Of the 198 fatalities in jump races, $68.7 \%$ were due to limb injury, $16.2 \%$ to cranial or vertebral injury and 3.5\% were sudden deaths. The risk of fatality in flat starts increased between 1989 and 2004 but the risk in jump starts remained unchanged over the 15 year period Boden et al. (2006).

Sudden death accounted for $26 \%$ of all fatalities on Victorian racetracks recorded during the study period, compared with $9 \%(58 / 659)$ of Thoroughbred racing fatalities reported in a Californian study (Johnson et al. 1994) and 12\% (15/127) in a British study (Boden et al. 2005). The causes of sudden were identified as induced pulmonary hemorrhage exercise $6 \%$ and $5 \%$ of hypersensitivity reactions in all cases were detected illicit drugs. These results differ from those reported in the literature. In Victoria, Australia there were 514 fatalities over the 15 year period; 316 in flat races and 198 in jump races (Boden et al. 2006). In a racing of Thoroughbreds in Britain, of the 2358 clinical events reported (1.05\% of all starts), 1937 involved the musculoskeletal system and 421 involved other body systems. Six hundred and fifty-seven incidents $(0.29 \%$ of starts) resulted in death or euthanasia. Eighty-one percent of limb injury reports involved forelimbs and $46 \%$ involved flexor tendons/suspensory ligaments. Nonlimb problems included epistaxis $(0.83 / 1000$ starts $)$, exhausted horse syndrome' (0.47/1000 starts) and paroxysmal atrial fibrillation (0.20/1000 starts). Incidents including fatalities per 1000 starts were 24.7 from chases, 19.45 from hurdle races, 8.46 from National Hunt flat races and 3.97 from flat races (Williams et al. 2001). A study of three large training yards in Newmarket, UK (2005-2007), a total of 248 injuries sustained in 217 horses met the inclusion criteria; 241 of these episodes were individual injury events (seven were re-injuries) (Ramzan \& Palmer 2011). In a study of 314 Quarter Horse racehorses with musculoskeletal injuries that were necropsies through the California Horse Racing Board Postmortem Program from 1990 to 2007. Musculoskeletal injuries accounted for 314 of the 443 (71\%) in Quarter Horse racehorses that died during the 18-year study period. Fatal musculoskeletal injuries occurred at a rate of 2.0 deaths $/ 1,000$ race starts and 18.6 deaths $/ 1,000$ horses that started a race. Musculoskeletal injuries occurred predominantly during racing (84\%) and in the forelimbs (81\%). The most common fatal musculoskeletal injuries were metacarpophalangeal and metatarsophalangeal joint (fetlock) support injuries (40\%) and carpal (24\%), vertebral $(10 \%)$, and scapular $(8 \%)$ fractures. Proximal interphalangeal (pastern) joint luxations resulted in death of 3\% of horses (Sarrafian et al. 2012).

The incidence of disease, mortality and survival of horses, focusing on locomotor problems, at riding schools were studied, using data from an animal insurance database during 1997-2002. In total 5140 horses from 136 riding schools were included in the analysis. The overall yearly incidence rate (IR) was 1584 events of veterinary care per 10,000 horse-years at risk (HYAR). The total and diagnostic mortalities were 790 and 763 deaths per 10,000 HYAR. Rates varied substantially among riding schools (Egenvall et al. 2009). Locomotor problems the rates were 1116 events of veterinary care and 524 deaths per 10,000 HYAR (Egenvall et al. 2009). Bone lesions in head, neck, chest, back and pelvis represent a high proportion $58 / 329$ (24\%). These results appear to be higher than those reported in California 4\% by Johnson et al. (1994), in Australia 4\% in Australia (Boden, et al. 2005), 19\% (Boden et al. 2006) California and 10\% (Sarrafian et al. 2012). Acute abdominal crisis (colic), corresponded to the second cause of death in horses at the track "La Rinconada", with a prevalence of $35 \%$ (189/532). Lesions of the digestive system in order of importance were presented in 38\% small bowel strangulation mainly twists with ischemic coagulation necrosis, stomach $31 \%$ gastric dilation and rupture, large intestine $20 \%$ torque, displacement and incarceration and $1 \%$ specifically esophagus esophagitis abscess. It is important to mention the condition of the peritoneum by $73 \%(138 / 189)$ of the cases studied. These results differ from those reported in the literature (Johnson et al. 1994), reporting a gastrointestinal disease associated mortality of $4 \%$. However, in a retrospective study done by Leblond et al. (2000) on the causes of death in horses in France, show that 21\% of death in horses is colic. Moreover, Rose \& Hodgson (1995) reported that the leading cause of death in horses is for acute abdominal crisis. The increase in cases associated with abdominal conditions is possibly due to failures in the management, diet and nutrition. 
Major definitive causes of sudden death included cardiac failure, apparent pulmonary failure, pulmonary haemorrhage, haemorrhage associated with pelvic fractures or with idiopathic blood vessel rupture, and spinal cord injury. A presumptive cause of death was made in $25 \%(67 / 268)$ of cases and death remained unexplained in $22 \%(58 / 268)$ of cases (Lyle et al. 2011). Sudden death can be attributed to a variety of causes. Causes of sudden death and the lesions found in cases of exercise-related sudden death are similar in different racing jurisdictions (Lyle et al. 2011). Although fatal musculoskeletal injuries have a low prevalence, milder forms of these injuries have a high prevalence (Stover 2003). Most of the submissions were Thoroughbred horses (432) and Quarter Horses (46). Most of the injuries occurred while racing (42\%) and in training sessions (39\%); with fewer non-exercise $(12 \%)$ and accident $(7 \%)$ related injuries or illnesses. Musculoskeletal injuries accounted for $83 \%$ of the Thoroughbred and $80 \%$ of the Quarter Horse submissions. The Thoroughbred horses incurred 306 fractures with 263 in the limbs and $90 \%$ of those in the forelimbs. The proximal sesamoid bone(s), third metacarpal bone and humerus were the most common bones fractured in Thoroughbred horses and Quarter Horses. Other major causes of death included respiratory, digestive and multi-organ system disorders (Johnson et al. 1994).

In Victoria, Australia, the risk of fatality was 0.44 per 1000 flat starts and 8.3 per 1000 jump starts ( 18.9 x greater). The risk of fatality on city tracks was 1.1 per 1000 starts whereas on country tracks it was 0.57 per 1000 starts. Of the 316 fatalities in flat races, $73.4 \%$ were due to limb injury, $2.5 \%$ to cranial or vertebral injury and $19.0 \%$ were sudden deaths. Of the 198 fatalities in jump races, $68.7 \%$ were due to limb injury, $16.2 \%$ to cranial or vertebral injury and $3.5 \%$ were sudden deaths. The risk of fatality in flat starts increased between 1989 and 2004 but the risk in jump starts remained unchanged over the 15 year period (Boden et al. 2006). Sudden death accounted for $26 \%$ of all fatalities on Victorian racetracks recorded during the study period, compared with 9\% (58/659) of Thoroughbred racing fatalities reported in a Californian study (Johnson et al. 1994) and $12 \%$ (15/127) in a British study (Boden et al. 2005). In Victoria, Australia there were 514 fatalities over the 15 year period; 316 in flat races and 198 in jump races (Boden et al. 2006). In a racing of Thoroughbreds in Britain, of the 2358 clinical events reported $(1.05 \%$ of all starts), 1937 involved the musculoskeletal system and 421 involved other body systems. Six hundred and fifty-seven incidents $(0.29 \%$ of starts) resulted in death or euthanasia. Eighty-one percent of limb injury reports involved forelimbs and $46 \%$ involved flexor tendons/ suspensory ligaments. Nonlimb problems included epistaxis (0.83/1000 starts), exhausted horse syndrome' $(0.47 / 1000$ starts) and paroxysmal atrial fibrillation $(0.20 / 1000$ starts $)$. Incidents including fatalities per 1000 starts were 24.7 from chases, 19.45 from hurdle races, 8.46 from National Hunt flat races and 3.97 from flat races (Williams et al. 2001). A study of three large training yards in Newmarket, UK (2005-2007), a total of 248 injuries sustained in 217 horses met the inclusion criteria; 241 of these episodes were individual injury events (seven were re-injuries) (Ramzan \& Palmer 2011).

\section{CONCLUSIONS}

The causes of death in Thoroughbred Race Horses in Caracas, Venezuela, were identified and described. The principal skeletal muscle injuries resulted in fractures euthanasia.

The abdominal crisis was mostly bowel twists and gastric rupture.

The respiratory pathologies such as pneumonia and pleuritis presented a significant number of cases of pulmonary hemorrhage induced by exercise.

The multisystem pathologies were present in fewest cases.

The high rate of mortality and euthanasia drastically affect the horse racing industry in Venezuela and worldwide.

Many jurisdictions have made multiple efforts in pre-race clinical and post-race toxicology tests to avoid foreign substances which may affect athletic performance and conceal musculoskeletal injuries.

The necropsy performed by the Equine Veterinary Pathologist can objectively elucidate the cause of death and promote preventive measures in cases of population medicine in the racetrack (infectious diseases: AIE, EEE, EEV, among others), but can also determine previous lesions not detected in the clinical examination, even in cases of sudden death (EIPH, aorta rupture), and can be determinant from the legal point of view for sanction of the authorities for those involved in the race of dead horses (veterinarian, trainer and owner).

\section{REFERENCES}

Aluja A. \& Constantino C. 2002. Técnicas de Necropsia en Animales Domésticos. 2a ed. Editorial El Manual Moderno, México, D. F. 103p.

Boden L., Anderson G., Charles J., Morgan K., Morton J., Parkin T., Slocombe R. \& Clarke A. 2006. Risk of fatality and causes of death of Thoroughbred horses associated with racing in Victoria, Australia: 1989-2004. Equine Vet. J. 38(4):312-318. http://dx.doi.org/10.2746/042516406777749182. PMid:16866197.

Boden L., Charles J., Slocombe R., Sandy J., Finnin P., Morton J. \& Clarke A. 2005. Sudden death in racing Thoroughbreds in Victoria, Australia. Equine Vet. J. 37(3):269-271. http://dx.doi.org/10.2746/0425164054530597. PMid:15892239.

Dutton H. 2007. The corticosteroid laminitis story. 1. Duty of care. Equine Vet. J. 39(1):5-6. http://dx.doi.org/10.2746/042516407X166792. PMid:17228586.

Egenvall A., Lonnell C. \& Roepstorff L. 2009. Analysis of morbidity and mortality data in riding school horses, with special regard to locomotor problems. Prev. Vet. Med. 88(3):193-204. http://dx.doi.org/10.1016/j. prevetmed.2008.10.004. PMid:19042047.

Johnson B., Stover S., Daft B., Kinde H., Read D., Barr B., Anderson M., Moore J., Woods L., Stoltz J. \& Blanchard P. 1994. Causes of death in racehorses over a 2 year period. Equine Vet. J. 26(4):327-332. http://dx.doi. org/10.1111/j.2042-3306.1994.tb04395.x. PMid:8575402.

Johnson P.J., Slight S.H., Ganjam V.K. \& Kreeger J.M. 2002. Glucocorticoids and laminitis in the horse. Vet. Clin. N. Am., Equine Pract. 18(2):219-236. http://dx.doi.org/10.1016/S0749-0739(02)00015-9. PMid:15635906.

Leblond A., Villard I., Leblond L., Sabatier P. \& Sasco A. 2000. A retrospective evaluation of the causes of death of 448 Insured French Horses in 1995. Vet. Res. Commun. 24(2):85-102. http://dx.doi.org/10.1023/A:1006408522233. PMid:10720095.

Lyle C., Uzal F., Mcgorum B., Aida H., Blissitt K., Case J., Charles J., Gardner I., Horadagoda N., Kusano K., Lam K., Pack J., Parkin T., Slocombe R., Stewart B. \& Boden L. 2011. Sudden death in racing Thoroughbred horses: an international multicentre study of post mortem findings. Equine Vet. J. 43(3):324-331. http://dx.doi.org/10.1111/j.2042-3306.2010.00164.x. PMid:21492210. 
Miller M., Moore G.E., Bertin F.R. \& Kritchevsky J.E. 2015. What's new in old horses? Postmortem diagnoses in mature and aged equids. Vet. Pathol.53(2):390-398. http://dx.doi.org/10.1177/0300985815608674. PMid:26459516.

Ramzan P. \& Palmer L. 2011. Musculoskeletal injuries in Thoroughbred racehorses: a study of three large training yards in Newmarket, UK (20052007). Vet. J. 187(3):325-329. http://dx.doi.org/10.1016/j.tvjl.2009.12.019. PMid:20089426.

Rose R.J. \& Hodgson D. 1995. Manual of Equine Practice. W.B. Saunders, Philadelphia, Pennsylvania, p.130-132.
Sarrafian T., Case J., Kinde H., Daft B., Read D., Moore J., Uzal F. \& Stover S. 2012. Fatal musculoskeletal injuries of Quarter Horse racehorses: 314 cases (1990-2007). J. Am. Vet. Med. Assoc. 241(7):935-942. http://dx.doi. org/10.2460/javma.241.7.935. PMid:23013508.

Stover S. 2003. The epidemiology of Thoroughbred racehorse injuries. Clin. Tech. Equine Pract. 2(4):312-322. http://dx.doi.org/10.1053/j. ctep.2004.04.003.

Williams R., Harkins L., Hammond C. \& Wood J. 2001. Racehorse injuries, clinical problems and fatalities recorded on British racecourses from flat racing and National Hunt racing during 1996, 1997 and 1998. Equine Vet. J. 33(5):478486. http://dx.doi.org/10.2746/042516401776254808. PMid:11558743. 